\title{
Public Sector Reform and Governance for Adaptation: Implications of New Public Management for Adaptive Capacity in Mexico and Norway
}

\author{
Hallie Eakin · Siri Eriksen • Per-Ove Eikeland • \\ Cecilie Øyen
}

Received: 3 September 2009/Accepted: 21 December 2010/Published online: 13 January 2011

(C) The Author(s) 2011. This article is published with open access at Springerlink.com

\begin{abstract}
Although many governments are assuming the responsibility of initiating adaptation policy in relation to climate change, the compatibility of "governance-foradaptation" with the current paradigms of public administration has generally been overlooked. Over the last several decades, countries around the globe have embraced variants of the philosophy of administration broadly called "New Public Management" (NPM) in an effort to improve administrative efficiencies and the provision of public services. Using evidence from a case study of reforms in the building sector in Norway, and a case study of water and flood risk management in central Mexico, we analyze the implications of the adoption of the tenets of NPM for adaptive capacity. Our cases illustrate that some of the key attributes associated with governance for adaptationnamely, technical and financial capacities; institutional memory, learning and knowledge; and participation and accountability—have been eroded by NPM reforms. Despite improvements in specific operational tasks of the
\end{abstract}

H. Eakin $(\bowtie)$

School of Sustainability, Arizona State University,

P.O. Box 875502, Tempe, AZ 85287-5502, USA

e-mail: Hallie.Eakin@asu.edu

S. Eriksen

Noragric, Norwegian University of Life Sciences,

P.O. Box 5003, 1432 Aas, Norway

P.-O. Eikeland

Fridtjof Nansen Institute, Lysaker, Norway

C. Øyen

Department of Architectural Design and Management,

Norwegian University of Science and Technology,

Oslo, Norway public sector in each case, we show that the success of NPM reforms presumes the existence of core elements of governance that have often been found lacking, including solid institutional frameworks and accountability. Our analysis illustrates the importance of considering both longer-term adaptive capacities and short-term efficiency goals in public sector administration reform.

Keywords Adaptive capacity - Climate change adaptation - Governance - New Public Management . Public policy $\cdot$ Latin America $\cdot$ Europe

\section{Introduction}

Adaptation to climate change is already occurring in both the private and public spheres as different actors respond autonomously to the experienced and anticipated threat of climate change. National governments are expected to take leadership in the formation of climate change policy and to provide the institutional arrangements to facilitate autonomous action (Eakin and Lemos 2006). These expectations have increased interest in defining the appropriate forms of governance for effective adaptation (e.g., see The Federal Ministry for Economic Cooperation and Development (BMZ) 2008), and there is a small but emerging academic literature on the subject (e.g., Eakin and Lemos 2006; Engle and Lemos 2010). Climate change and resilience literatures have argued that the success of institutions and societal organization in building adaptive capacity rests on such factors as the constraints on actors' decision-making, the fit between institutions and ecosystems and appropriate levels of responsibilities and decision making to facilitate community adaptation (Adger 2001; Armitage 2005; Folke and others 2007; Næss and others 2005; Berkes 2007; 
Nelson and others 2007; Olsson and others 2007). Empirical observations show that shifts in economic policy, such as the transition from a centrally planned to a marketoriented economy in Vietnam (Adger 2000), also have implications for institutional frameworks and adaptive capacity.

Nevertheless, there has been relatively little investigation of how shifts in modes of governance (i.e., "the set of regulatory processes, mechanisms and organizations through which political actors influence environmental actions and outcomes," Lemos and Agarwal 2006: 298) may facilitate or inhibit adaptive action. In particular, public sector policies and structures over the past 20 years have been globally influenced by "New Public Management" (NPM), a philosophy of administration associated with neoliberal public sector reforms. While these reforms have altered the structure and operation of public administration in both developing and industrial-world contexts, their implications for adaptation to climate change have not been explored. Indeed, much of the research on adaptation governance has been relatively theoretical rather than empirical in focus (Yohe and Tol 2001; Tompkins and Adger 2005; Smit and Wandel 2006).

We aim to address this shortcoming by analyzing the potential tensions between NPM and adaptive-capacity building. We have looked at ways that NPM has affected governance and adaptive capacity and the institutional fit between the objectives of NPM and the requirements for managing evolving climate-change risks. To illustrate our argument, we present two case studies of reforms in particular public sectors and these sectors' capacity for managing climate variability (as a proxy for the addressing the day-to-day challenges implicit in climate change): the first looks at Norway's housing sector and the second the management of flood risk in Mexico. Although the political, economic and geographic contexts of these cases are fundamentally different, they illustrate certain similar implications for adaptation to climate change following the adoption of NPM reforms, providing us with important lessons about the implications of public administration ideology for adaptive capacity.

We start with a conceptual discussion of adaptive capacity and specific aspects of governance that have been shown to be important for such capacity. Next, we explore the literature on NPM reforms and implications for governance structures more generally. Third, we draw on both literatures to describe how NPM reforms may alter governance arrangements that affect society's capacities to adapt to changing climatic conditions. After presenting the two case studies, we discuss the similarities and differences across the two geographic and sector contexts to draw conclusions on how NPM has enabled or constrained adaptive capacity.

\section{Adaptive Capacity and Governance for Adaptation}

Central to the discussion of governance and climate change adaptation is the question of whether institutions and agencies are conducive to the creation, dissemination and processing of knowledge (learning), and whether decisionmakers have the legitimacy and accountability needed to take leadership in matters affecting such adaptation (Adger and others 2005). Lessons from natural-resource management, applied to conditions of climate change, illustrate that flexible institutions that allow decision-makers to revise and reformulate policy as new information emerges tend to be more effective in face of uncertainty (Tompkins and Adger 2005). Institutions influence the technical and financial capacity of implementing organizations, affecting their ability to plan and implement adaptation actions (Ivey and others 2004). Institutional organization may structure access to power and resources that facilitate or constrain adaptation for specific sets of actors, as shown for example by Eakin (2006). Thus the rules, norms and modes of decision-making affect how a society organizes its resources and knowledge to protect itself against harm from climate change (Nelson and others 2007).

While adaptive capacity or adaptability is not equivalent to the concept of resilience, it is a fundamental characteristic of a resilient system (Walker and others 2004). Adaptive capacity is the ability of particular actors (or components of a system) to influence institutional structures and the resilience of the system of which they are a part (Berkes 2007; Walker and others 2004). Recent work on the linkages between institutions, adaptive capacity and system resilience has recognized the failures of top-down, rigid and centralized processes to respond to environmental change, suggesting that polycentric, multilevel and participatory governance structures may be more conducive to building resilience in face of stressors such as climate change (Ostrom 2001). This research theorizes that the latter governance structures enable learning, provide the basis for social memory, increase the diversity and quality of knowledge available for adaptation, and provide the best basis for trust and collaboration in problem solving (Pahl-Wostl and others 2007; Plummer and Armitage 2007).

In support of these theoretical insights, Kumler and Lemos (2008) found that water-management reforms in the Paraíba do Sol River Basin in Brazil that created polycentric and more democratic nodes of decision-making improved opportunities for learning and resulted in governance that appeared more responsive and flexible in face of severe drought. Tompkins (2005) describes inter-agency and cross-scale planning leadership by the National Hurricane Committee in the Cayman Islands that proved instrumental in mobilizing public participation and collaboration in 
hurricane preparedness. This and other research illustrate the role of citizen participation, decentralized planning and the inclusion of diverse knowledge sources in mitigating environmental risks.

Nevertheless, other empirical research has shown that in practice, decentralizing and democratizing the decisionmaking process on key concerns associated with planning and climate-change adaptation can be problematic (Engle and Lemos 2010). A case study of coastal management found that financial constraints, access to information, mandate limitations and the time horizons of public-sector decision processes affected local capacities to make strategic decisions about anticipated sea level rise (Few and others 2007). While public-private partnerships hold considerable promise in mobilizing resources for adaptation (Adger and others 2005), devolving control over technology and knowledge formation to the private sector may not adequately address the needs of the most vulnerable (Eakin and Lemos 2006).

Although more research is needed, the evidence suggests that participation in decision-making, access to knowledge and other resources, and the responsibility of decision-makers to constituencies are issues of particular salience to adaptation. Nevertheless, relatively few empirical studies have questioned how new trends in public governance, occurring independently of accumulating knowledge about adaptation, affect societal adaptive capacity. To what extent are reforms in public administration, completed or underway, compatible with a polycentric, multilevel and participatory governance style? In the current policy environment, responses to climate change are likely to emerge from experience rather than theory. It is important, therefore, for close investigations at a sector or practical level to determine whether shifts in governance and public administration-reforms in technical and financial capacity; learning, institutional memory and knowledge; and participation, empowerment and accountability-are improving or constraining key facets of adaptive capacity.

\section{New Public Management}

New Public Management emerged under the Thatcher and Reagan Governments in the United Kingdom and United States respectively as part of a broader neoliberal focus on policy and public administration taken place all over the world. Championed in part by World Bank and IMF structural adjustment programs, NPM-inspired reforms have since become widespread. Despite national variation in the scope and depth changes, NPM reforms originate in similar economic theories and normative values, placing economic efficiency and budgetary control as priorities for government. The often-stated aims of these reforms are to enhance the responsiveness of government to citizens, to stretch the effectiveness of scarce public resources and to move decision-making closer to the constituents of the public sector.

Devolution of responsibility and power to lower levels of government, a core feature in NPM programs. has involved demarcating commercial from non-commercial activities of public agencies and encouraging public agencies to adopt profit-maximising, cost-cutting and business-development goals similar to those of private corporations (Painter 2001; Self 2000). In this businessoriented model of administration, constituents of reformed public agencies are often referred to as "customers and clients," rather than citizens with entitlements (Box 1999; Christensen and Lægreid 2001).

With this devolution of responsibility the discretionary power of managers becomes stronger and subordinate governmental levels and agencies act with more autonomy through (a) the separation of political and administrative functions (e.g., "let politicians set the goals and civil servants implement them"), (b) the separation of administrative functions within the same organisation, or (c) the transfer of authority from one organisation to another downward in the hierarchy or to new subordinate governmental organisations (Grønlie and Selle 1998). By transferring power to managers and splitting agencies into specialised single-purpose organizations, NPM reforms aim to streamline functions and reduce redundancy and waste. For activities considered best implemented directly by the private sector, outsourcing has emerged as a core policy goal: specific services and functions (e.g. maintenance, control, advice) are contracted out to private companies in the belief that specialisation and competition encourage cost cutting and economic efficiency, and thus enhances the use of public resources.

Achieving greater efficiency in public-service provision and administration has brought about some unintended and unanticipated consequences, many now well-documented in the literature. Particularly salient in a discussion of governance for adaptation to climate change are the implications of NPM for participatory and democratic decision-making: whether NPM impedes opportunities for addressing complex long-term and multisectoral problems; whether NPM erodes accountability in public agencies; and whether a government loses moral credibility in socialenvironmental interactions because of the high priority given to economic efficiency above all else.

While NPM reformers advocate decentralizing decisions and reducing bureaucratic obstacles to decision making (the principle "let managers manage"), observers often find a counteracting centralization of power and control at lower levels of government. This centralization, 
detrimental to public participation, is probably a consequence of emulating private business practices and incentive structures that emphasize "making the managers manage" (Christensen and Lægreid 2007, p. 8). True political decentralisation to democratically elected lowerlevel representatives or civil society stakeholders has seldom been a priority weighed against the contrary goal of increased decision-making efficiency. As one critic of NPM has stated, "Market-driven managerialism can run counter to self-governance, as it is structured around the idea of happy consumers rather than involved citizens" (Box 1999, p. 35).

The concurrent concern that the adoption of NPM has resulted in an erosion of public agencies' capacities to deal with complex problems has arisen partly in relation to the refocusing of public administration on specific operational objectives with measurable indicators and tangible outcomes. The consequence of this refocus has reduced public-sector attention on the achievement of complex goals in favor of greater emphasis on realizing more measurable one-dimensional outcomes (Dunleavy 1995; Davis 1997; Weller and others 1997; Painter 2001; Terry 2005).

Further contributing to the 'hollowing out' of public sector policy capacity are such features of NPM publicsector reforms as privatization, the devolution of functions and expertise by government departments to alternative service delivery systems or supra-national institutions, and limitations on the discretionary roles and functions of senior public servants (Rhodes 1994). Terry (2005) argues that NPM has resulted in thinner and more fragile government agencies with reduced regulatory capacities, diminished abilities to reinforce social norms and values, and weaker skills in interpreting, adapting to and guiding social change.

A loss of accountability, particularly affecting the relationship between the public sector and less vocal citizens, has also been observed as another unintended effect of NPM (Christensen and Lægreid 2002). The decline in accountability appears to be a result of streamlining decision-making processes, which in turn diminishes the role of debate and dissent in the policy process (e.g., less learning by interaction) (Painter 2001). New incentive structures put in place by private sector agents that take over outsourced tasks have also had adverse effects on accountability. In many cases contractual terms are primarily self-serving for the private actor, thus by-passing and undermining the NPM motivating principals of greater efficiency (Hood 1998; Painter 2001).

Increased vertical and horizontal specialization and fragmentation associated with NPM reforms have been linked to disjointed access to resources and services and an increased potential for conflicts among policy objectives and goals. This problem has produced a wave of
post-NPM-reforms, resulting in increased centralization, new efforts at capacity building and co-ordination (Christensen and Lægreid 2007). In contrast to the economic logic, which dominated the initial NPM reforms, these new reforms apply a more holistic strategy, using insights from the other social sciences (Bogdanor 2005). This 'whole government' counter-reform process aspires to achieve horizontal and vertical coordination in order to eliminate situations in which different policies undermine each other, make better use of scarce resources, create synergies by bringing together different stakeholders in a particular policy area and offer citizens seamless rather than fragmented access to services (Pollitt 2003).

It is important to acknowledge that similarities in the direction and characteristics of administrative reforms adopted during the 1980s and 1990s define NPM better than by any well-defined doctrine or suite of adoption administrative tools. While generalizations about the policy reforms associated with NPM are possible, their adoption always reflects local institutional histories, cultures and policy goals. By bringing existing concerns and opportunities associated with the implementation of NPM together with insights on adaptive capacity and governance emerging in the theoretical literature, we have identified several thematic areas in which the aims of NPM and adaptive capacity-building intersect, to highlight the difference between the anticipated outcomes of NPM and expectations for adaptive capacity (Table 1). We selected these three thematic areas because of their salience in both the NPM and adaptive-capacity literatures; we do not claim that Table 1 captures either the characteristics of NPM or adaptive capacity comprehensively.

In the next section we present two very different case studies of risk management and adaptation to environmental change in the context of New Public Management. In each case, we first examine the public sector reforms carried out at the national level and ways in which they represent a shift away from governance conditions conducive for adaptation. Next we investigate how key facets of adaptive capacity — of the building sector in Norway and the water sector in Mexico-have been directly or indirectly affected by NPM reforms. Presenting a case of NPM reforms from an emerging economy and new democracy (Mexico) together with a case from a country with a long history of democratic process and political stability (Norway) highlights the commonalities of intent and structure that define NPM reforms in both contexts. Although these two studies initially were neither designed for comparison nor shared a common research approach, identification of similarities through comparative analysis of two diverse geographic contexts is particularly fruitful for eliciting generalizable lessons rather than case-specific results. Our concern is not whether the NPM reforms were effective in 
Table 1 Key areas of potential influence of NPM reforms on the adaptive capacity of sectors and actors

\begin{tabular}{|c|c|c|}
\hline & Potential positive effects on adaptive capacity & Potential negative effects on adaptive capacity \\
\hline $\begin{array}{l}\text { Technical and financial } \\
\text { capacities }\end{array}$ & $\begin{array}{l}\text { More efficient allocation of resources to where } \\
\text { they are required }\end{array}$ & $\begin{array}{l}\text { A hollowing out of public sector regulatory, technical } \\
\text { and financial capacity due to shift in objectives from } \\
\text { professionalism to economic efficiency and due to a } \\
\text { devolution of functions and expertise from government } \\
\text { departments to alternative service delivery systems }\end{array}$ \\
\hline $\begin{array}{l}\text { Learning, knowledge, } \\
\text { institutional memory }\end{array}$ & $\begin{array}{l}\text { Devolution of responsibilities, enhancing the } \\
\text { representation of local knowledge and increasing the } \\
\text { autonomy of subordinate governmental levels in } \\
\text { responding to local needs }\end{array}$ & $\begin{array}{l}\text { Divisions of operational and policy functions in public } \\
\text { agencies, leading to policy fragmentation, } \\
\text { undermining ability to address complex long-term } \\
\text { multisectoral issues, and inhibiting information } \\
\text { exchange and responding to local needs }\end{array}$ \\
\hline $\begin{array}{l}\text { Participation, } \\
\text { empowerment, } \\
\text { accountability }\end{array}$ & $\begin{array}{l}\text { Enhanced responsiveness of government to citizens as } \\
\text { customers/clients; Decentralized decision making to } \\
\text { where problems are experienced }\end{array}$ & $\begin{array}{l}\text { Loss of accountability, potential centralization of power } \\
\text { within managerial and commercial actors rather than } \\
\text { elected representatives or civil society stakeholders }\end{array}$ \\
\hline
\end{tabular}

achieving their stated goals, but rather how the process of implementing NPM reforms may have affected adaptive capacity and vulnerability to present and future environmental change in the specific geographic contexts in which the reforms were adopted.

\section{Case 1: Climate Adaptation in the Pre-Fab Housing Industry of Norway}

The initiative to restructure public-sector administration and management in Norway began in the early 1990s, emerging from a National Commission report (Ministry of Consumer Affairs, Administration 1989). The push for reforms was motivated in part by recognition of the state's involvement in the provision of too many goods and services, with functions extending from administration and regulation to direct ownership and operation of traditional industrial activities. Changes in technology, values, and ideology, including new attention to tenets of neoliberalism and individual choice and responsibilities, provided further motivation. The Commission recommended focusing policy on issues of strategic significance, while decentralizing the practical implementation of goals and guidelines, under the slogan 'better governance at large and less governance in detail'.

Sectoral reforms followed the Commission report in the early 1990s, initially incorporating the energy sector and then expanding to telecommunications and postal services. A new commission report in 2000 (Ministry of Government Administration and Reform 2000) advocated replacing public monopolies with competitive markets and encouraging public agencies to outsource service and supply and to stress efficiency and quality indicators, and to consider constituents as "clients" (Ministry of Government Administration and Reform 2000).

\section{Reforms in the Building Sector}

Revised in 1997, the Norwegian Planning and Building Act (NPBA) sought to clarify liability and responsibility of different actors in the building sector in order to reduce the number of building defects originating in planning, design and construction (Eriksen and others 2009). Before the reform, municipal authorities responsible for approving applications for building permits played an active role in controlling the technical standards of various building projects. After the reform, responsibility for both building design and enforcing construction standards clearly fell to the private sector. Municipal authorities now must ensure that construction companies have the necessary registrations and control systems in place, but in practice, the authorities check only that the required paperwork has been submitted, not that the plans and design for the project nor that the finished housing meet the building code's technical standards (Nørve 2005; Øyen 2005). Local authorities are supposed to supervise a sample of approximately $10 \%$ of all building permit applications; however, only a very small fraction of projects are actually supervised, and the controls put in place by the companies themselves are often not satisfactorily implemented (although this issue is now being addressed in an amendment to the NPBA).

The NPBA-mandated shift in construction planning responsibilities and functions from the public to private sectors is particularly relevant for adaptive capacity in a country of extremely varied, but almost uniformly harsh climatic conditions. The variability in these conditions and attendant risks across the country demands a comparable diversity of locally adapted solutions. While some southern and coastal areas have a temperate climate (mild winters), the rest of the country has either polar- or sub-arctic climate characteristics. Heavy precipitation combined with strong winds presents a particular challenge to 
infrastructure and buildings along the western and northern coast in Norway. Local effects of future global warming are likely to vary greatly. The average temperature is projected to rise between 2.5 and 3.5 centigrade, with the largest temperature changes inland and in the north (Benestad 2002; Hanssen-Bauer and others 2003; Iversen and others 2005). Most of the warming is likely to occur during winter months, while precipitation may increase by up to $20 \%$, especially in western and northern coastal areas and during the autumn.

The anticipated climate trends are likely to exacerbate existing harsh climatic conditions and increase the risk of such natural disasters as heavy precipitation and wind events. In addition, freezing, thawing and large snowfalls are challenges that may intensify with climate change in southeastern parts of the country. Many defects in residential housing, such as the penetration of moisture, are due to exposure to particular climate stresses over time and are not covered by hazard insurance. While building standards and quality have generally improved over the last decade, the costs of correcting faults and repairing defects, including those from penetration of moisture and rotting, remain high, amounting to about 13 billion NOK ( 3 billion USD) or $10 \%$ of annual capital invested in new buildings.

As a result of the NPBA reforms, decisions regarding building design and structure are not only now relegated to the private sector (rather than municipalities and local governments) but also increasingly concentrated within the private sector with large national or regional companies or commercial investors, rather than local builders. The new responsibilities and administrative functions assigned to private sector actors have required increased administrative and financial capacity. Consequently, small companies are merging with larger companies or joining national chains and franchises in order to survive in the construction industry (Eriksen and others 2009).

For this case, we draw from the findings of a study that investigated decision-making, information flow and practical adaptation actions in the housing sector in Norway, further described in Eriksen and others (2007, 2009). The study was carried out as a qualitative case study in the pre-fab housing industry of Norway, coupled with an analysis based on a theoretical study of publications focused on climate change, NPM and building processes in Norway. The study involved 36 interviews, carried out in 2005-2007, incorporating public officials in municipal offices from six municipalities, active in planning and building services, property administration, urban development and environmental administration, and managers and craftsmen from four different manufacturers of prefabricated housing (for further details, see Eriksen and others 2007, 2009). The manufacturers and municipalities were located in different climate zones in Norway (see Fig. 1).
Fig. 1 Climatic variations and study sites, Norway case (Eriksen and others 2009)

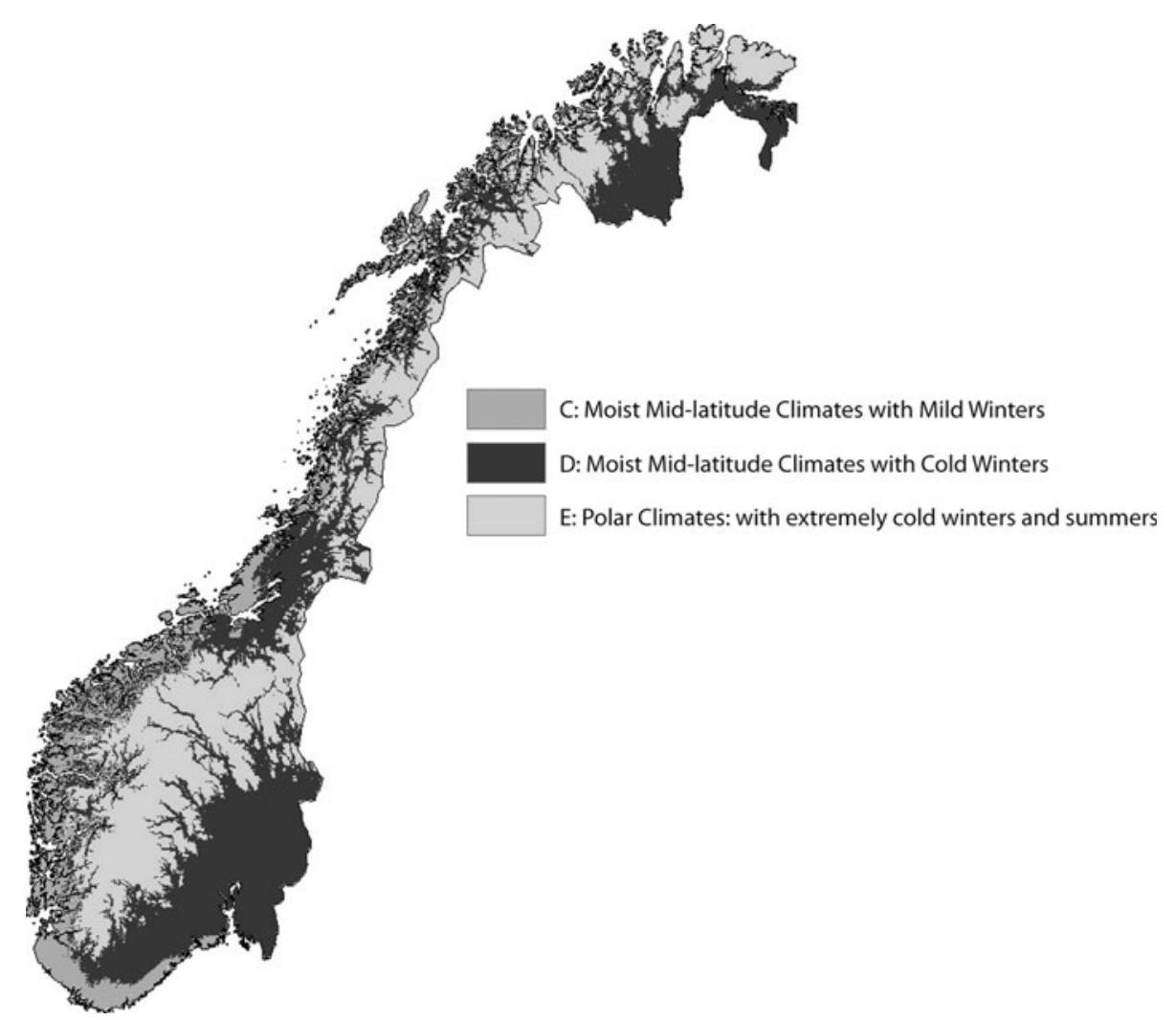


Technical and Financial Capacities

The transfer of responsibilities to the private sector resulted in a reduction of technical personnel in local administrations, which in turn contributed to a loss of accumulated experience and knowledge of building sector needs, vulnerabilities, and successful experiences with adaptation. Their responsibilities were reduced to routine administrative functions, for which paperwork has considerably increased creating an additional burden on personnel. Local employees are no longer involved in the learning processes regarding how to address present and future risks to housing from climate variability and change.

In contrast, it is not clear whether the private-sector building companies themselves have lost or gained technical and financial capacities per se through this reform. In order to meet the new professional and administrative requirements mandated in the sector reforms, companies have responded with a higher level of 'professionalization.' Some of the larger firms have strengthened systems of technical support for projects. However, these capacities do not necessarily incorporate existing or new local adaptation knowledge; instead, it appears that expertise regarding national legal and technical requirements may have been strengthened at the expense of differentiated knowledge of specific local geographic and social conditions.

The merging of small firms within larger companies has created a new bias towards centralized building designs and standards. In the past, both builders and municipal authorities had expertise in building solutions well-adapted to local conditions, and their knowledge served to enhance outcomes synergistically during building projects. This synergism has largely been lost through the reform, and local adaptation is now more dependent on the expertise of the building companies. Although we have limited data on change in the financial capacities of building companies since the 1997 reforms, there is some initial evidence that the larger companies with greater financial capacity and presence are now dominating the sector (Eriksen and others 2007, 2009).

\section{Institutional Memory and Knowledge}

Prior to the building sector reforms, standards and approaches to construction design (such as shape of the roof or the siting of the building in accordance with the prevailing wind direction) to withstand local climatic conditions developed into local building styles and traditions. This accumulated knowledge was institutionalized in local governments that were responsible for contracting builders and approving construction projects. Such local knowledge is critical for adaptation to climate variability and change because formal regulations alone, even if they are regionally differentiated, cannot sufficiently capture the local differences and changes in climatic conditions (Eriksen and others 2009). Formal regulations can nevertheless contribute to retaining local knowledge by making climate change adaptation and geographically differentiated solutions a focus area and by ensuring that such considerations are required in any planning. Other focus areas, such as fire safety and Universal Design (accessibility considerations) have, however, so far taken priority.

In theory, NPM type reforms of the late 1990s should increase use of local knowledge and provide greater flexibility in standards to suit local conditions through decentralization. In this case, however, the devolution of decision-making and the centralizing trend within the building sector have led building companies to become more dependent on information from sources other than the municipalities and local authorities. Eriksen and others (2009) observed large variations in knowledge about climate adaptation among local builders that are part of larger companies. Larger firms may have good access to new technology and information that can be used to strengthen local building solutions. An effective learning process, however, is dependent on a bottom-up information flow in which local experiences are incorporated into the company's development of technical solutions and decisions through routine reporting and feedback. A short "distance" from the local craftsman to the decision-maker regarding design is critical for creation of locally-adapted solutions. Where the distance is great, information flow tends to be top-down, and knowledge of centralised designs and procedures becomes more important than knowledge of local climate conditions and building solutions, inhibiting adaptive capacity.

\section{Participation, Empowerment and Accountability}

The shift in accountability from the municipal administration to the manufacturers has ostensibly clarified responsibilities, but has simultaneously introduced new problems. Builders are now responsible for monitoring themselves ('self-reporting') and their adherence to codes. The NPM principle of 'citizen participation and empowerment through the buying powers associated with the role of a consumer' now places the burden on the consumer to demand good climate solutions. Private actors are legally responsible for building according to existing regulations, but raising climate considerations with the customer is now only a matter of ethics. Most citizen-consumers have little insight into the most appropriate locally-adapted construction solutions and trust the builder to provide any necessary local adjustments. Individual consumers have tended to focus instead on aesthetic aspects such as the decoration of kitchen and bathrooms. Without advocacy by 
municipalities and citizen groups, it is unlikely there will be a higher prioritization of locally adapted climate solutions in building design and construction.

In practice, the NPM reforms have meant that the market is now indirectly driving building solutions and design. The emphasis on efficiency has led to a focus on the economics of building manufacture rather than social and public concerns associated with risk and adaptation to climate change. The manufacturers' efforts to reduce production time and enhance economies of scale run counter to such local adaptation efforts as constructing extra wind barriers where needed. In some cases local carpenters are making unauthorized and undocumented adaptations to changing climate conditions that may well lead to better adapted housing, but which could also produce faults and defects that may be difficult to identify at a later stage. Without a transparent and accountable process for addressing climate risk to housing in particular localities, local knowledge and experience may be lost, and any local adjustments are likely to be made in an ad hoc and unregulated manner, introducing new problems of accountability should such adjustments fail.

\section{Case 2: New Public Management and Risk of Flooding in Mexico}

The implementation of substantial public sector administrative reforms, many of which have been associated with the NPM paradigm, began in the mid-1990s in Mexico's Ministry of the Controllership and Administrative Development (Cedujo 2008). This period marked a significant change in Mexico's economic engagement with the world and a radical change in its domestic political environment. The Fox Administration (2000-2006) took up the baton of administrative reform, begun in the previous Zedillo Administration, calling for a more streamlined, transparent and efficient public service (Cedujo 2008).

Over the last two decades and in various contextsranging from civil protection to public utilities to poverty alleviation-diverse administrative and operational functions have been transferred to lower level governments, state agencies and municipal authorities. Efforts to enhance transparency and access to information has also become a priority for Mexican public agencies (Cedujo 2008), and most government agencies at the state and federal levels now have elaborate internet sites designed to facilitate the provision of necessary services and information to citizenclients (Klingner 2000). Features of the NPM paradigm have emerged as key characteristics of the 1990s policies and reform programs implemented in the water sector, and, by extension, in flood-risk management.
National Water Policy Reforms and NPM

Until the early 1990s, flood management was primarily the responsibility of the Secretary of Agriculture and Hydrological Resources (SARH), a highly centralized, technocratic and powerful federal agency. In 1992, a National Water Law was enacted that clearly reflected the administrative philosophy of NPM. This new law was designed to improve water access and supply by recuperating more of the costs of water administration, and, importantly, by granting concessions for water-supply administration to municipal governments and quasi-private agencies (Wilder and Romero Lankao 2006). The law also sought to improve the participation of local government, water users and the private sector in the management of water provision and sanitation, and mandated that states and local governments take over water infrastructure investments and maintenance (Comisión Nacional del Agua 2003; Cohen and González Reynoso 2005).

At the sub-national level, the state of Mexico ${ }^{1}$ created a State Water Commission (CAEM, or Comisión del Agua del Estado de México) in 1999. Congruent with national water reforms, state water management policy aimed to be self-sustaining, using fees to generate financial resources, increase investment in water infrastructure, promote greater participation of the private sector in the construction of public works and eliminate the financial burden for water management on the state and municipios (a political unit roughly equivalent to a U.S. county). Rather than perform these functions directly, CAEM assists, through information and technical support, municipal governments and "decentralized water management agencies" (quasiprivate organizations at the municipio level) in water management activities.

The findings of a study of flood management of the Upper Lerma Valley (see Fig. 2) carried out in 2004 and 2005 illustrates the potential effects of these reforms for adaptive capacity. The study evaluated the institutional capacity for flood-risk management in the Upper Lerma Valley in an effort to illuminate how policy-making, governance and disaster response interact to influence capacity for adaptation to climate change. The project involved 48 interviews with public officials in federal, state and municipal offices who were active in water, agriculture, civil protection, urban development and environmental administration. (For full details of the approach and methodology of this study, see Eakin and Appendini 2008, Eakin and others 2010).

\footnotetext{
1 The state of Mexico is one of the 31 sub-national administrative units (states) within the country of the same name.
} 
Fig. 2 Flooded sites and study municipios along the Upper Lerma River, State of Mexico (Eakin and Appendini 2008)

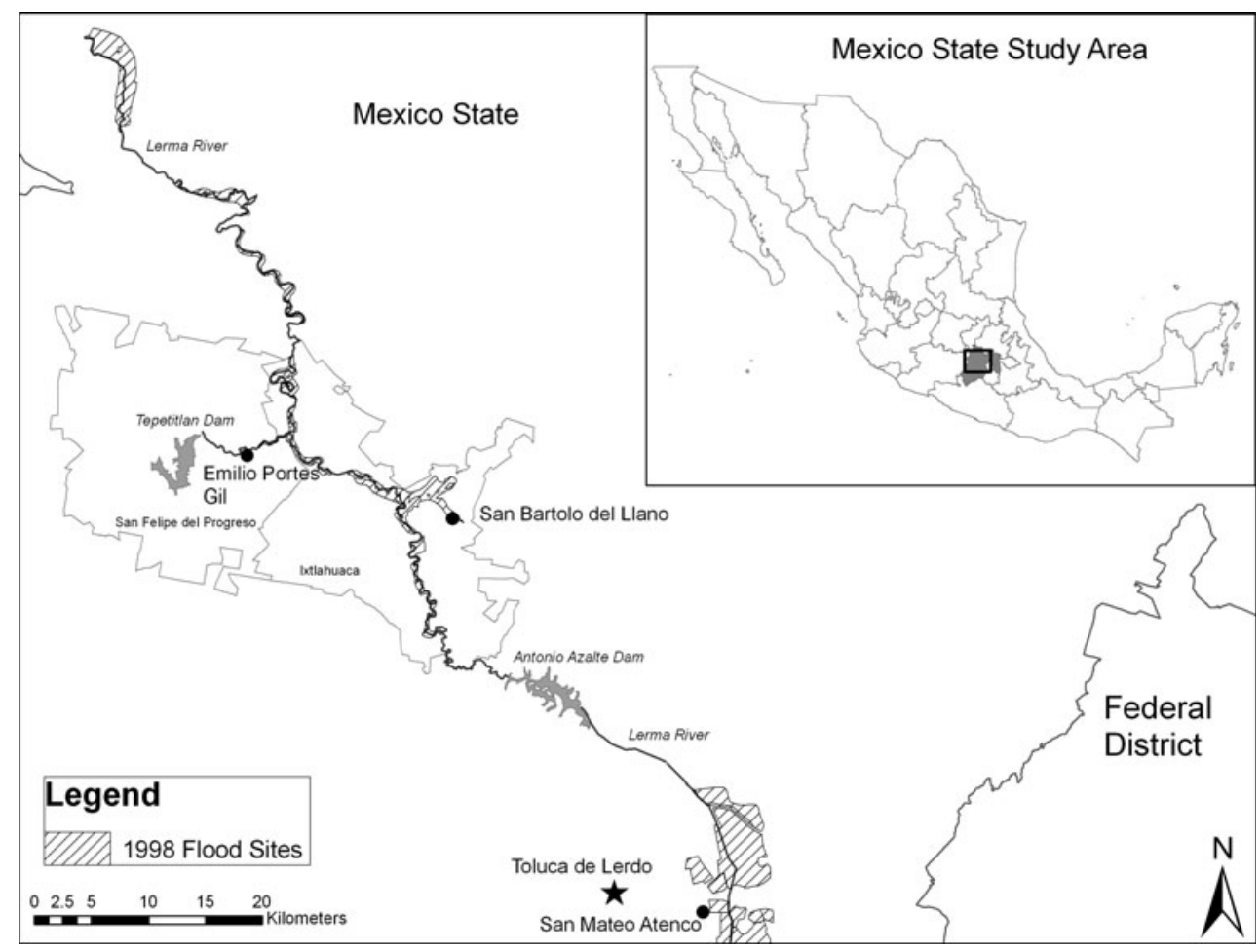

Flood Management in the Upper Lerma Valley

The Upper Lerma Valley, just west of Mexico City incorporates one of Mexico's most densely populated regions, the Toluca Valley (del Mazo González and others 2001). While flooding has always been a concern in the Valley, the frequency of flood events increased significantly after the institutional reforms of the early 1990s. According to the state's Civil Protection office, over the period 1994-2005 both the frequency of flood events and the number of municipios affected doubled in the Upper Lerma Valley (Fig. 2). The number of media reports of flood-related disasters in the state also more than doubled in the same period (DesInventar, www.desinventar.org). There is some evidence that rainfall has become more intense in the region (Groisman and others 2005), suggesting that precipitation may contribute to increasing flood risk in the future. In fact, while most climate-change scenarios for central Mexico anticipate diminished average annual rainfall, there are also indications that the hydrological cycle will intensify, resulting in more frequent and severe extremes events (Instituto Nacional de Ecología 2009). In face of the prospect of increased flood risk, the institutional context governing flood management and planning is likely to play a central role in enabling or diminishing adaptive capacity, particularly at the level of municipal authorities who are now in charge of designing local level interventions to reduce vulnerability from present, and ideally, future flood events.
According to the new state and federal water laws, municipalities and quasi-private water service organizations have now added to their roles in water service provision and become primarily responsible for managing flood risk by undertaking such activities as infrastructure investment, canal dredging and drainage. These agencies are also responsible for land-use planning, zoning and control of residential developments. Not surprisingly, these new responsibilities have been accompanied by technical, financial, and accountability challenges.

\section{Technical and Financial Capacities}

To respond effectively to the changing nature of flood risk, local governments must maintain the hydrological infrastructure for which they are responsible proactively and effectively. Following NPM principles, the quasi-private water operating organizations, now in charge of water service provision, are intended to be semi-autonomous, recuperating their operating costs through water user fees, and investing these funds in infrastructure maintenance. They also must pay the state for water allocated through the state water system (which, in turn, has been purchased in block from the federal government). Interviewees in the federal National Water Commission (CONAGUA) and CAEM (the state agency) acknowledged, however, that very few of the operators have been able to recuperate the cost of service provision, let alone infrastructure investment and maintenance. Most are in debt to CAEM, which 
in turn has crippled CAEM's financial capacities, and increased its debt to CONAGUA.

Even if local administrations had the financial capacity to engage in planning for climate change adaptation, they would need technical knowledge about hydrological and climatic trends and scenarios to inform the revision of technical standards for canal construction, sluices, bridges and dam operations. At the federal and state level, the reduction in operational activities of CONAGUA and CAEM has diminished the capacity for monitoring trends and changes in water resources just at the time when such monitoring is becoming increasingly important for climatechange adaptation. A CONAGUA official estimated that huan resources in their organization have been diminished by $80 \%$ since the start of the 1990 s. Although the resources of CONAGUA are now intended to be allocated to monitoring activities, the interviewees acknowledged that few officials have the time to do more than simply collect, $\log$ and distribute bulletins of data on the country's hydrological systems and climate. CONAGUA's diminished resources for both scientific and operational activities are also reflected in the declining investment in its meteorological stations, eroding the national capacity for monitoring climate changes. In a region in which land subsidence is already a substantial problem and past events are less and less predictive of future hydrological behavior, inadequate technical knowledge and information exchange can result in maladaptive investments: infrastructure that may actually increase risks from future flooding (see Eakin and Appendini 2008).

\section{Institutional Memory and Knowledge}

Effective flood management under climate change requires knowledge not only about the past and current status of the socio-ecosystem, but also about ongoing and future changes of this system over time. While some of this knowledge is contained in available documents, plans, maps and information systems, much of it resides in the expertise of individuals and organizations. One of the expected gains from decentralization was the ability of governments to tap into this local knowledge and experience. Yet if local administrations are constantly changing, leveraging this knowledge for policy development is difficult. Every three years the entire staff and leadership in a municipal administration is likely to change following new elections and the persistence of practices of patronage and clientelism locally. While CAEM offers specific training programs in water management to the private operators who are increasingly responsible for infrastructure and service provision in municipios, these operators also rarely last for more than one municipal administration. Accumulated knowledge, experience and even basic data and monitoring information are typically lost in this process.

Participation, Empowerment, and Accountability

According to interviews, the water reforms that were intended to enhance transparency and participation in decision-making (through decentralization and cost-recuperation), have not significantly changed the institutional culture of water management. In part, the lack of constituent participation in public administration may be due to a significant degree of historical distrust of local authorities. Interviewees in two rural communities affected by flooding in 2003 revealed that residents were more likely to rely on the state government by activating historical channels of patronage (personal contacts and political links) rather the municipal authorities who had the official mandate for action on flood-risk mitigation (e.g., dredging, levee or bridge maintenance). Following the 2003 flooding, for example, affected residents who were more politicallyconnected submitted hand-written appeals for compensation directly to the state Secretary of Agriculture. While the legal responsibility for organizing a public response to crisis lies with the municipal governments, the threat of protests by affected communities arrayed outside the door of the Secretary of Agriculture typically motivated the state agency to respond rapidly.

While more avenues for participating democratically in disaster-management activities have been legislated, it remains the case that the most politically-mobilized flood 'victims' are the ones who are able to provoke an operational response. The continued reliance on extra-legal avenues to provoke action from the government not only means that democratic channels are ignored at the local level, but it also suggests that the "client-oriented" strategy of the water reform Law is not necessarily streamlining accountability to the most vulnerable and least-powerful. The fragmented nature of flood interventions and water management thus raises important questions about what agency or group of agencies, and at what administrative scales, have the mandates, capacities and mechanisms of accountability to lead the region in enhancing capacity for adaptation to changing flood risk.

Overall, the general goals of NPM the reforms adopted in the mid-1990s in the water management sector appear to be poorly aligned with the institutional needs and capacities for flood-risk management. The inadequacy of the NPM-reforms to address the social and ecological complexity of flood risk provides opportunities for the persistence of engrained institutional modes of operation. Mexico's institutional culture is still very much intact, and the "democratic checks and balances, social controls, and oversight mechanisms" considered necessary for NPM 
success are not (yet) in place (Arrellano-Gault 2000, p. 403). Other analyses of NPM implementation in Mexico have noted that expectations of public participation and client-oriented service provision are impeded by the lack of civil society organizations and inexperience with the democratic process (Cabrero-Mendoza 2000). As a result, local governments may now have more responsibilities, but in many cases local leadership relies on private-sector consultants, officials at higher levels of administration or local political bosses (caciques) to compensate for deficiencies in capacity (Cabrero-Mendoza 2000). Nevertheless, even if implemented as intended, it is not clear that NPM would be an effective approach for flood-risk management. Enhanced public participation and more efficient local management of resources would still not address the fundamental mis-match of decentralized "client-based" service provision in the water sector and the coordinated cross-sector, watershed-scale and longer-term vision necessary for reducing flood risk.

\section{Discussion}

The implementation of NPM-type policy reforms in both Norway and Mexico reveal tradeoffs that militate against improvement in local adaptive capacity, and, particularly in the case of Norway, have potentially negative impacts. The greater efficiency of service provision that we describe in the two case studies-whether the service is economical housing built to clear regulations and standards, or water supply and management-were undoubtedly necessary in both countries. Nevertheless, the changes in policy and administration have not improved capacities for addressing the complex, inter-sector and cross-scalar concerns that are central to climate-change risk. In Norway, NPM may well have reduced adaptive capacities to respond to climatic stresses in the housing sector. In Mexico, trends in flood disasters suggest that the new institutional arrangements have had no effect in reducing flood risk. In both countries difficult problems concerning accountability and the participation of different stakeholders in the adaptation process have arisen from NPM-type reforms.

Both cases illustrate problems of institutional fit, in which institutional reforms have restructured control over, and participation in, risk reduction in ways that do not match the spatial and temporal scale of the hazard (Folke and others 2007). Because of the multiple social, ecological, political and economic factors that contribute to social vulnerability in particular places, coordination across scales and sectors is critical. In the Mexican case, the combination of decentralization of resource planning to local governments and quasi-private sector agencies has reduced interventions in flood-risk management to very limited, highly local problems: a backed-up drain, or segment of a river that requires dredging. Broader social and ecological processes underlying flooding are no longer central to the mandates of any of the legally responsible agencies, and there is little evidence that the shift in responsibilities has resulted in an increase in economic efficiency. In Norway, cutting the cost of housing production has taken precedence over enhancing flexibility and locally-adapted solutions. Public officials are now focused on filing paperwork rather than taking leadership in adaptation policy. While local responses to climate risk have been shown to be highly appropriate, the process of devolution - in principle to local entities - has conversely centralized standards and housing design in large national housing and construction companies.

In both contexts, as key regulatory and planning functions have been devolved to lower-scale administrative agencies and the private sector, decision-making has become fragmented. Such devolution and decentralization per se is not necessarily contrary to adaptation. It is generally agreed that adaptation needs to be enacted at the scale at which impacts occur, such that specific populations react to and anticipate climate-related impacts where they live and conduct their day-to-day activities (Smit and Wandel 2006). Flood risk management, however, may well be an exception to this assumption. Flooding is truly a system process, involving the interaction of factors at spatial and administrative scales that are often removed from the local site of flood damage. Where private economic benefits are clear, enhanced private-sector participation in decision-making and control over technology development might streamline adaptation processes. In the cases presented here, however, the policy reforms have not allowed greater participation of vulnerable stakeholders in decision-making and, in the case of Norway, may have actually reduced such participation.

The effect of NPM-type reforms have led to further concerns about the technical and human resources that are fundamental for enhancing adaptive capacity. The devolution of responsibilities from public to private sectors in both case studies reduced technical (and in some cases financial) expertise in the public sector., Although the reforms have enhanced some formal technical expertise in the private sector, much informal local knowledge, so critical for adaptation, has been lost. In the Mexican water sector, the loss of staff in the state and federal water commissions has led to a reduction in a capacity for monitoring and anticipating system-wide changes in water resources. There is a danger that water management is being reduced to day-to-day operational activities at the expense of longer-term anticipatory action. Similarly, in Norway the loss in technical expertise is evident as municipal administrations no longer assess the quality of 
housing in technical terms but merely check formalities in building applications. These findings reinforce concerns raised by Ivey and others (2004) and Few and others (2007) that transfers of resources and expertise often do not follow the shift in responsibilities from the state to local people and agencies. The hollowing out of existing state capacities often associated with NPM (Terry 2005) exacerbates the threat to adaptive capacity.

Further problems arise from the high turnover in personnel in the public sectors in both countries that undermines institutional memory and reduces opportunities for learning. In both the Mexican water sector and the Norwegian building sector, the expertise that could be harnessed for adaptation is not an embedded characteristic of institutions themselves, but rather of the individuals who work in them. Thus in Norway, the privatized and centralized regulation of construction and housing design has contributed to loss of local knowledge regarding building solutions that are adapted to particular climate conditions. The erosion of public-sector expertise has weakened the exchange of information between municipal administrations and private firms, an exchange previously critical for learning how to reduce risk in specific geographic contexts. The loss of local knowledge is a particular threat to adaptive capacity because reliance on formal regulation alone will not ensure the differentiated adaptation that is required.

Poor accountability and empowerment remain concerns in both countries, although, given the distinct institutional contexts, the problem emerges differently in each case. In Mexico, the National Water Commission no longer has the capacity for the research necessary to anticipate climate impacts on infrastructure, and it is not clear what agency will be meeting those needs in specific geographic contexts. In the Norwegian housing sector, while the devolution of functions to the private sector has clarified and centralized responsibilities, the process appears to have diffused accountability. Customers do not have the expertise to ensure that housing as delivered is well adapted to local climate conditions, and municipal authorities are not responsible for ensuring that the constructed housing is appropriate. Some of the very local adaptations that do occur are therefore informal and not subject to monitoring, and national firms are unlikely to be responsible for any problems associated with such adaptations.

One of the premises of NPM is that public services can be largely driven by citizen "client" demands, but providing the 'service' of proactive climate adaptation, particularly to vulnerable populations that have little influence or command over markets or public policy, is a dubious proposition. In Mexico, local governments now have more responsibilities, and as the political process became more democratic, participation in decision-making was expected to improve. However, reforms intended to enhance participation and transparency have not in practice changed the existing institutional culture of water management, and a long-standing distrust in local authorities persists. As Arellano-Gault (2000, p. 403) writes, NPM "is being applied despite a lack of solid institutional frameworks, rule of law, weak checks and balances, civil service systems, and effective accountability systems" that are considered prerequisites of NPM in many developed countries.

The result is a continued reliance on extra-legal avenues which essentially by-pass the local government, and perpetuate traditions of patronage, clientelism and ad hoc responses to climate-related disasters. Thus, even when some populations are able to exert pressure and express demand for improved services, there is no guarantee that their interests are representative of a broader vulnerable public, or that the responses they elicit from the agencies responsible for service provision will address broader needs. These observations underscore previous suggestions that decentralization that does not deal with existing power structures and institutional weaknesses may reinforce inequities and fail to address the vulnerability of those most at risk (Nelson and others 2007; Plummer and Armitage 2007). However, more effective and participatory decisionmaking will have little effect over adaptive capacity if the institutions that govern those decisions are inappropriate to the temporal scope and scale of the risks they face. In the Mexican case in particularly, NPM appears to be an inappropriate model of institutional reform for managing the nature of flood risk.

\section{Conclusion}

Beyond the specific domain of disaster-risk management, adaptation to climate extremes is a relatively new subject for public policy and public administration. As adaptation to climate change emerges as a concern of government at different scales, there is a need to evaluate how forms of governance can influence adaptive capacity. We do not argue that the principles of New Public Management are inherently averse to adaptation to climate change. However, our case studies do illustrate that philosophies concerning the organization and structure of public administration can enable or impede adaptive capacity. As a result of two decades of evaluations of New Public Management-inspired policies in diverse geographic and socio-political contexts, NPM has evolved in ways that depart from its philosophical origins, and, in some contexts, has changed in ways that may actually enhance adaptive capacities by improving efficiencies and basic service provision. Nevertheless, the case studies described here indicate that there remain serious issues concerning 
NPM's effect on the capacity of public sector agencies to anticipate risk and prepare for climate change, the need to address local needs and concerns, and concerning government accountability to vulnerable populations.

If these problems are to be counteracted, solid institutional frameworks and accountability systems need to be put in place as part of any governance reform. Climatechange adaptation must be the explicit responsibility of a legal entity provided with sufficient financial and technical resources to carry out its responsibilities in practice and to develop networks for learning and partnerships for decision-making between fragmented public and private actors. Within such an institutional system, maintaining people's well-being in the face of climate change must constitute a citizen right rather than a customer "demand."

Acknowledgments The authors appreciate the helpful comments of the anonymous reviewers of this manuscript. Support for the Norweigan empirical research presented in this article was from the SINTEF Building and Infrastructure research and development program "Climate 2000-Building Constructions in a More Severe Climate", strategic institute projects "Impact of Climate Change on the Built Environment" and "Weather Protection in the Construction Process" as well as the University of Oslo Potentials of and Limits to Adaptation in Norway project. Some of the research forms part of the $\mathrm{PhD}$-study of one of the authors within the Climate 2000 program. The authors gratefully acknowledge all construction industry partners and the Research Council of Norway. A special thanks to the interviewees and the Norwegian Joinery Manufacturers Association (Boligprodusentene). We would like to thank Sjur Kasa, Anders Underthun, Kim Robert Lis $\varnothing$ and Tore Kvande for invaluable inputs throughout the research project. The Mexican case study research was supported by a National Science Foundation International Fellowship to H. Eakin (\#0401939). The map for the Mexican case study was prepared by A. Lerner. Any opinions and interpretations expressed in this article are those of the authors and not of the funding agencies.

Open Access This article is distributed under the terms of the Creative Commons Attribution Noncommercial License which permits any noncommercial use, distribution, and reproduction in any medium, provided the original author(s) and source are credited.

\section{References}

Adger WN (2000) Institutional adaptation to environmental risk under the transition in Vietnam. Annals of the Association of American Geographers 90:738-758

Adger WN (2001) Scales of governance and environmental justice for adaptation and mitigation of climate change. Journal of International Development 13:921-931

Adger WN, Arnell NW, Tompkins E (2005) Successful adaptation to climate change across scales. Global Environmental Change $15: 77-86$

Arellano-Gault D (2000) Challenges for the new public management: organizational culture and the administrative modernization program in Mexico City (1995-1997). American Review of Public Administration 30:400-413

Armitage D (2005) Adaptive capacity and community-based natural resource management. Environmental Management 35:703-715
Benestad RE (2002) Empirically downscaled temperature scenarios for Northern Europe based on a multi-model ensemble. Climate Research 21:105-125

Berkes F (2007) Understanding uncertainty and reducing vulnerability: lessons from resilience thinking. Natural Hazards 41:283-295

Bogdanor V (2005) Introduction. In: Bogdanor V (ed) Joined-up government. British academy occasional paper 5. Oxford University Press, Oxford, pp 1-18

Box R (1999) Running government like a business: implications for public administration theory and practice. American Review of Public Administration 29:19-43

Cabrero-Mendoza E (2000) Mexican local governance in transition: fleeting change or permanent transformation? American Review of Public Administration 30:374-388

Cedujo G (2008) Explaining change in the Mexican public sector: the limits of new public management. International Review of Administrative Sciences 74:111-127

Christensen T, Lægreid P (2001) A transformative perspective on administrative reforms. In: Christensen T, Lægreid P (eds) New public management. The transformation of ideas and practice Ashgate, Aldershot. England and Burlington, USA, pp 13-39

Christensen T, Lægreid P (2002) New Public Management: puzzles of democracy and the influence of citizens. The Journal of Political Philosophy 10:267-295

Christensen T, Lægreid P (2007) Introduction-theoretical approach and research questions. In: Christensen $\mathrm{T}$, Laegreid $\mathrm{P}$ (eds) Transcending new public management-the transformation of public sector reforms Ashgate, Aldershot. England and Burlington, USA, pp 1-16

Cohen MP, González Reynoso AE (2005) ¿Guerra por el agua en el Valle de México? Estudio sobre las relaciones hidráulicas entre el Distrito Federal y el Estado de México. Coordinación de Humanidades. PUEC, UNAM y Fundación Friedrich Ebert, Mexico City

Davis G (1997) Towards a hollow state? Managerialism and its critics. In: Considine M, Painter M (eds) Managerialism. The great debate. Melbourne University Press, Melbourne, pp 208-223

del Mazo González LA, Martínez Baca IA, Figueroa Rodríguez DG, Suárez López IJ (2001) Programa hidráulico integral del estado de México 2002-2025. Comision del Agua del Estado de Mexico. http://redlerma.uaemex.mx/images/PDFs/PROGRAMA $\% 20$ HIDRAULICO\%20INTEGRAL\%202002-2025.pdf. Accessed 24 July 2009

Dunleavy P (1995) Policy disasters: explaining the UK's record. Public Policy and Administration 10:52-70

Eakin H (2006) Weathering risk in rural Mexico: economic, climatic and institutional change. University of Arizona Press, Tucson, p 242

Eakin H, Appendini K (2008) Livelihood change, farming, and managing flood risk in the Lerma Valley, Mexico. Agriculture and Human Values 25:555-566

Eakin H, Lemos MC (2006) Adaptation and the state: Latin America and the challenge of capacity-building under globalization. Global Environmental Change 16:7-18

Eakin H, Lerner A, Murtinho F (2010) Adaptive capacity in evolving peri-urban spaces: response to flood risk in the Upper Lerma River Valley, Mexico. Global Environmental Change 20:14-22

Engle N, Lemos MC (2010) Unpacking governance: building adaptive capacity to climate change of river basins in Brazil. Global Environmental Change 20(1):4-13

Eriksen S, Øyen CF, Kasa S, Underthun A (2007) Klimatilpasning og fuktsikring i typehussektoren (in Norwegian). Climate adaptation and moisture safety in the building sector. Climate 2000 project report 3. SINTEF Building and Infrastructure, Oslo 
Eriksen S, Øyen CF, Kasa S, Underthun A (2009) Weakening adaptive capacity? Effects of organisational and institutional change on the housing sector in Norway. Journal of Climate and Development 1:111-129

Few R, Brown K, Tompkins E (2007) Climate change and coastal management decisions: insights from Christchurch Bay, UK. Coastal Management 35:255-270

Folke C, Pritchard L, Berkes F, Colding J and Svedin U (2007) The problem of fit between ecosystems and institutions: ten years later. Ecology and Society 12(1):Article 30 [online]

Groisman PY, Knight RW, Easterling DR, Karl TR, Hegerl GC, Razuvaev VAN (2005) Trends in intense precipitation in the climate record. Journal of Climate 18(9):1326-1350

Grønlie T, Selle P (eds) (1998) Ein stat? Fristillingas fire ansikt. Samlaget, Oslo

Hanssen-Bauer I, Førland EJ, Haugen JE, Tveito OE (2003) Temperature and precipitation scenarios for Norway: comparison of results from dynamical and empirical downscaling. Climate Research 25:15-27

Hood C (1998) The art of the state: culture. Rhetoric and public management. Clarendon Press, Oxford

Instituto Nacional de Ecología (2009) México. Cuarta comunicación nacional ante la convención marco de las naciones unidas sobre el cambio climático. Instituto Nacional de Ecología/Programa de las Naciones Unidas sobre el Desarrollo

Iversen T, Benestad R, Haugen JE, Kirkevåg A, Sorteberg A, Debernard J, Grønås S, Hanssen-Bauer I, Kvamstø NG, Martinsen EA, Engen-Skaugen T (2005) RegClim. Norges klima om 100 år. Usikkerhet og risiko (in Norwegian). Uncertainty and Risk. Meteorologisk Institutt/Institutt for geofag/Bjerknessenteret for klimaforskning. http://regclim.met.no. Accessed 5. May 2009

Ivey J, Smithers J, de Loe RC (2004) Community capacity for adaptation to climate-induced water shortages: linking institutional complexity and local actors. Environmental Management 33:36-47

Klingner DE (2000) South of the border Progress and problems in implementing new public management reforms in Mexico today. American Review of Public Administration 39:365-373

Kumler L, Lemos MC (2008). Managing waters of the Paraíba do Sul River Basin, Brazil: a case study in institutional change and social learning. Ecology and Society 13(2):article 22

Lemos MC, Agarwal A (2006) Environmental governance. Annual Review of Environment and Resources 31:297-325

Ministry of Consumer Affairs and Administration (1989) En Bedre Organisert Stat (in Norwegian). A better organised state. NOU, 1989:5. Ministry of Consumer Affairs and Administration, Oslo

Ministry of Government Administration and Reform (2000) Should the public sector be exposed to competition? NOU, 2000:19. Ministry of Government Administration and Reform, Oslo

Nacional Comisión, del Agua (2003) Programa Hidráulico regional 2002-2006 Región VIII Lerma Santiago Pacífico. DF. Comisión Nacional del Agua, Mexico City, México

Næss LO, Bang G, Eriksen S, Vevatne J (2005) Institutional adaptation to climate change: flood responses at the municipal level in Norway. Global Environmental Change 15:125-138

Nelson D, Adger WN, Brown K (2007) Adaptation to environmental change: contributions of a resilience framework. Annual Review of Environment and Resources 32:395-419

Nørve S (2005) Bedre Kontroll over Byggevirksomheten? En evaluering av kommunal iverksetting og byggeforetakenes endrede kontrollpraksis (in Norwegian). Improved Control over Construction Activities? Norges byggforskningsinstitutt, Prosjektrapport 390, Oslo

Olsson P, Folke C, Galaz V, Hahn T, Schultz L (2007) Enhancing the fit through adaptive co-management: creating and maintaining bridging functions for matching scales in the Kristianstads Vattenrike biosphere reserve, Sweden. Ecology and Society 12:article 28

Ostrom E (2001). Vulnerability and polycentric governance systems. International Human Dimensions Programme Update 3:article 1

$\varnothing$ yen CF (2005) Statutory provisions-attention and actions in local administration, planning, design and construction, NBI Note 69. Norwegian Building Research Institute, Oslo

Pahl-Wostl C, Craps M, Dewulf A, Mostert E, Tabara D, Taillieu T (2007) Social learning and water resource management. Ecology and Society 12:Article 5

Painter M (2001) Policy capacity and the effects of new public management. In: Christensen T, Lægereid P (eds) New public management. The transformation of ideas and practice. Ashgate, Hampshire. England and Burlington, USA, pp 209-229

Plummer R, Armitage D (2007) A resilience-based framework for evaluating adaptive co-management: linking ecology, economics and society in a complex world. Ecological Economics 61:62-74

Pollitt C (2003) Joined-up government: a survey. Political Studies Review 1:34-49

Rhodes RAW (1994) The hollowing out of the state: the changing nature of the public service in Britain. Political Quarterly 65:138-151

Self P (2000) Rolling back the market: economic dogma and political choice. Macmillan Press, London, p 251

Smit B, Wandel J (2006) Adaptation, adaptive capacity and vulnerability. Global Environmental Change 16:282-292

Terry LD (2005) The thinning of administrative institutions in the hollow state. Administration and Society 37:426-444

The Federal Ministry for Economic Cooperation and Development (BMZ) (2008) International policy workshop climate governance and development, in preparation for the world development report 2010. September 28-30, 2008. InWent-Capacity Building International and The World Bank, Berlin

Tompkins E (2005) Planning for climate change in small islands: insights from national hurricane preparedness in the Cayman Islands. Global Environmental Change 15(2):139-149

Tompkins E, Adger WN (2005) Defining response capacity to enhance climate change policy. Environmental Science and Policy 8:562-571

Walker B, Holling CS, Carpenter SR and Kinzig A (2004) Resilience, adaptability and transformability in social-ecological systems. Ecology and Society 9:5. http://www.ecologyandsociety.org/ vol19/iss2/art5

Weller P, Bakvis H, Rhodes RAW (1997) The hollow crown: countervailing trends in core executives. Palgrave Macmillan, Basingstoke, UK 272

Wilder M, Romero Lankao P (2006) Paradoxes of decentralization: water reform and social implications in Mexico. World Development 34:1977-1995

Yohe G, Tol RSJ (2001) Indicators for social and economic coping capacity-moving toward a working definition of adaptive capacity. Global Environmental Change 12:25-40 